\title{
Purkinje Cell NMDA Receptors Assume a Key Role in Synaptic Gain Control in the Mature Cerebellum
}

\author{
Claire Piochon, ${ }^{1,2 *}$ Carole Levenes, ${ }^{2 \star}$ Gen Ohtsuki, ${ }^{1,3}$ and Christian Hansel ${ }^{1,3}$ \\ ${ }^{1}$ Department of Neurobiology, University of Chicago, Chicago, Illinois 60637, 2Université Pierre et Marie Curie-Paris 6, Unité Mixte de Recherche 7102, \\ Centre National de la Recherche Scientifique, Laboratoire Neurobiologie des Processus Adaptifs, Equipe Developpement et Vieillissement du Systeme \\ Nerveux, 75005 Paris, France, and ${ }^{3}$ Department of Neuroscience, Erasmus University Medical Center, 3000 DR, Rotterdam, The Netherlands
}

A classic view in cerebellar physiology holds that Purkinje cells do not express functional NMDA receptors and that, therefore, postsynaptic NMDA receptors are not involved in the induction of long-term depression (LTD) at parallel fiber (PF) to Purkinje cell synapses. Recently, it has been demonstrated that functional NMDA receptors are postsynaptically expressed at climbing fiber (CF) to Purkinje cell synapses in mice, reaching full expression levels at $\sim 2$ months after birth. Here, we show that in the mature mouse cerebellum LTD (induced by paired PF and CF activation), but not long-term potentiation (LTP; PF stimulation alone) at PF to Purkinje cell synapses is blocked by bath application of the NMDA receptor antagonist $D$-2-amino-5-phosphonovaleric acid (D-APV). A blockade of LTD, but not LTP, was also observed when the noncompetitive NMDA channel blocker MK-801 was added to the patch-pipette saline, suggesting that postsynaptically expressed NMDA receptors are required for LTD induction. Using confocal calcium imaging, we show that CF-evoked calcium transients in dendritic spines are reduced in the presence of D-APV. This observation confirms that NMDA receptor signaling occurs at CF synapses and suggests that NMDA receptor-mediated calcium transients at the CF input site might contribute to LTD induction. Finally, we performed dendritic patch-clamp recordings from rat Purkinje cells. Dendritically recorded CF responses were reduced when D-APV was bath applied. Together, these data suggest that the late developmental expression of postsynaptic NMDA receptors at CF synapses onto Purkinje cells is associated with a switch toward an NMDA receptor-dependent LTD induction mechanism.

\section{Introduction}

NMDA receptors are key players in the induction of long-term potentiation (LTP) at glutamatergic synapses onto hippocampal and neocortical pyramidal cells (Bliss and Collingridge, 1993). Early whole-cell patch-clamp recordings suggested that, in contrast, cerebellar Purkinje cells do not express functional NMDA receptors (Perkel et al., 1990; Llano et al., 1991). Recently, however, it was shown that NMDA receptors are indeed postsynaptically expressed at climbing fiber (CF) to Purkinje cell synapses in mice, but that they show a late developmental onset: they are barely detectable until the fourth week after birth (Piochon et al., 2007), and reach full expression levels at $\sim 8$ weeks after birth (Piochon et al., 2007; Renzi et al., 2007). A more recent study has demonstrated an NMDA component in CF-evoked EPSCs recorded in 2-3-month-old rats (Bidoret et al., 2009), showing that

\footnotetext{
Received Aug. 18, 2010; revised Sept. 23, 2010; accepted Sept. 27, 2010.

This work was supported by grants from the French Foundation for Medical Research to C.P., a Netherlands Organization for Scientific Research (NWO-ALW) grant, Brain Research Foundation Grant BRF SG 2009-7, and National Institutes of Health Grant AA016540 to C.H. We are grateful to Claude Meunier (Laboratory of Neurophysics and Physiology, Paris, France) and members of the Hansel laboratory for invaluable comments on the manuscript. ${ }^{*}$ C.P. and C.L. contributed equally to this work.

Correspondence should be addressed to Christian Hansel, Department of Neurobiology, University of Chicago, Chicago, Illinois 60637. E-mail: chansel@bsd.uchicago.edu.

C. Levenes' present address: Université Paris Descartes, CNRS-Laboratory of Neurophysics and Physiology, 45 rue des St. Pères, 75006 Paris, France.

D0I:10.1523/JNEUROSCI.4344-10.2010

Copyright $\odot 2010$ the authors $\quad 0270-6474 / 10 / 3015330-06 \$ 15.00 / 0$
}

functional NMDA receptors are not only expressed at CF to Purkinje cell synapses in the mature mouse cerebellum, but also in adult rats.

The predominantly studied form of cerebellar plasticity is long-term depression (LTD) at parallel fiber (PF) to Purkinje cell synapses, which results from PF and CF coactivation and is assumed to mediate forms of cerebellar motor learning (Ito et al., 1982; Ito, 2002). CF activity provides widespread calcium transients (Ross and Werman, 1987; Konnerth et al., 1992; Miyakawa et al., 1992), which are required for PF-LTD induction (Sakurai, 1990; Konnerth et al., 1992). Postsynaptic LTP results from isolated PF stimulation (Lev-Ram et al., 2002; Coesmans et al., 2004) and lower calcium transients (Coesmans et al., 2004), and might provide a reversal mechanism for LTD. Previous recordings from young adult Purkinje cells failed to demonstrate a role of postsynaptic NMDA receptors in PF-LTD induction. In studies using postnatal day $(\mathrm{P})$ 15-P26 rats, it was suggested that presynaptic, but not postsynaptic NMDA receptors located at PF terminals are involved in LTD (Casado et al., 2002; Bidoret et al., 2009). However, this claim has been challenged by the observation that NMDA receptor blockade affects neither calcium transients in PF terminals (Shin and Linden, 2005; Qiu and Knöpfel, 2007) nor the frequency of miniature EPSCs (Shin and Linden, 2005). Another study showed that in young mice (P25-P35) both PF-LTD and PF-LTP are NMDA receptor independent (Canepari and Vogt, 2008). 
The recent observation that functional NMDA receptors are postsynaptically expressed at CF to Purkinje cell synapses at a late developmental onset (Piochon et al., 2007; Renzi et al., 2007) suggests that Purkinje cell NMDA receptors might play a role in PF synaptic plasticity, but that a switch toward an NMDA receptor-dependent LTD or LTP mechanism can only occur late during maturation. Here, we examined the role of Purkinje cell NMDA receptors in slices obtained from 2-6-month-old mice. We show that postsynaptic NMDA receptors are involved in LTD, but not in LTP induction, and demonstrate an NMDA receptor-mediated component in dendritic CF responses and in spine calcium transients.

\section{Materials and Methods}

The experiments were performed at two sites: the Universite Pierre et Marie Curie (see Fig. 1) and the University of Chicago (see Figs. 2, 3, 4). Differences in saline solutions or procedures used are outlined below. All animal procedures described were performed in accordance with the guidelines of the French Ministry of Agriculture and the European Community, and with a protocol approved by the Animal Care and Use Committee of the University of Chicago.

Slice preparation. Sagittal slices of the cerebellar vermis $(180-220 \mu \mathrm{m})$ were prepared from either 2-6-month-old mice (C57BL/6) or P25P66 rats (Sprague Dawley), and were kept at room temperature in artificial CSF (ACSF) containing the following (in mM): $124 \mathrm{NaCl}, 5$ $\mathrm{KCl}, 1.25 \mathrm{Na}_{2} \mathrm{HPO}_{4}, 2 \mathrm{MgSO}_{4}, 2 \mathrm{CaCl}_{2}, 26 \mathrm{NaHCO}_{3}$, and 10 D-glucose (Université Pierre et Marie Curie: $130 \mathrm{NaCl}, 2.5 \mathrm{KCl}, 1.3$ $\mathrm{NaH}_{2} \mathrm{PO}_{4}, 1 \mathrm{MgCl}_{2}, 2 \mathrm{CaCl}_{2}, 26 \mathrm{NaHCO}_{3}$, and $10 \mathrm{D}$-glucose) bubbled with $95 \% \mathrm{O}_{2}$ and $5 \% \mathrm{CO}_{2}$. Throughout recording, slices were continuously perfused with ACSF that was supplemented with picrotoxin $(100 \mu \mathrm{M})$ or bicuculline methiodide $(20 \mu \mathrm{M})$ to block $\mathrm{GABA}_{\mathrm{A}}$ receptors. All drugs were purchased from Sigma, except for Oregon Green BAPTA-2 (Invitrogen).

Somatic whole-cell patch-clamp recordings. Patch-clamp recordings from the Purkinje cell soma were performed at room temperature using an EPC-10 amplifier (HEKA Electronics), or an Axopatch-200A amplifier (Molecular Devices). Currents were filtered at $2-5 \mathrm{kHz}$, digitized at $8-40 \mathrm{kHz}$, and acquired using PULSE software (HEKA Electronics) or ACQUIS1 software (Bio-Logic). Patch pipettes (2-5 M 2 ) were filled with a solution containing the following (in $\mathrm{mM}$ ): $9 \mathrm{KCl}, 10 \mathrm{KOH}, 120$ K-gluconate, $3.48 \mathrm{MgCl}_{2}, 10 \mathrm{HEPES}, 4 \mathrm{NaCl}, 4 \mathrm{Na}_{2} \mathrm{ATP}, 0.4 \mathrm{Na}_{3} \mathrm{GTP}$, and 17.5 sucrose, pH 7.25-7.35 (Université Pierre et Marie Curie: $6 \mathrm{KCl}$, $144 \mathrm{~K}$-gluconate, $4.6 \mathrm{MgCl}_{2}, 10 \mathrm{HEPES}, 1 \mathrm{EGTA}, 0.1 \mathrm{CaCl}_{2}, 4 \mathrm{Na}_{2} \mathrm{ATP}$, and $0.4 \mathrm{Na}_{3} \mathrm{GTP}$ ). In some recordings, MK-801 ( $1 \mathrm{mM}$; one LTD recording: $3 \mathrm{~mm}$ ) was added to the pipette saline. Purkinje cells were voltage clamped at holding potentials in the range of -65 to $-70 \mathrm{mV}$. To evoke synaptic responses, PFs and CFs were activated using glass electrodes filled with ACSF. For PF stimulation, electrodes were placed in the upper molecular layer to reduce the risk of unintentional CF stimulation. For CF stimulation, electrodes were placed in the granule cell layer, just underneath the recorded Purkinje cells. In all experiments, the paired-pulse ratio (PPR) was monitored using paired-pulse stimulation (interval 40 $\mathrm{ms}$ ) at a frequency of $0.05 \mathrm{~Hz}$. Tetanization protocols were applied in current-clamp mode. For LTD induction, $100 \mathrm{~Hz}$ PF stimulation (8 pulses) was followed $120-150 \mathrm{~ms}$ later by single-pulse CF stimulation. For LTP induction, $100 \mathrm{~Hz}$ PF stimulation was applied in isolation. NMDA receptor blockade (quantified for the MK-801 experiments performed at near-physiological temperature, shown in supplemental Fig. 2, available at www.jneurosci.org as supplemental material) caused a reduction of complex spike afterhyperpolarizations during tetanization (control: $7.0 \pm 0.7 \mathrm{mV} ; n=5$; MK-801: $3.5 \pm 0.7 \mathrm{mV} ; n=4 ; p<0.05$, Mann-Whitney $U$ test), but did not significantly affect other stimulus parameters. Both protocols trigger predominantly postsynaptic forms of LTD and LTP, respectively, as suggested by small, but insignificant PPR changes (LTD: $103.3 \pm 5.4 \% ; n=13$; LTP: $90.4 \pm 4.2 \% ; n=6 ; t=32-42$ $\min ; p>0.05$ ) (supplemental Fig. 1, available at www.jneurosci.org as supplemental material). Series and input resistance were monitored throughout the experiments by applying hyperpolarizing voltage steps
$(-10 \mathrm{mV})$ at the end of each sweep. Recordings were excluded if series or input resistances varied by $>15 \%$ over the course of the experiments. All values were averaged over time (three successive responses recorded at $20 \mathrm{~s}$ intervals) and are shown as a percentage of baseline (calculated from the last $5 \mathrm{~min}$ of baseline recording) \pm SEM. For statistical analysis, we used the Student's $t$ test (paired/unpaired) and the Mann-Whitney $U$ test, when appropriate.

Dendritic patch-clamp recordings. To measure dendritic CF responses, we performed patch-clamp recordings at distances of $\sim 70-130 \mu \mathrm{m}$ from the soma. Patch formation was done with differential interference contrast optics in combination with near-infrared (IR) light illumination (IR-DIC) using a Zeiss AxioCam MRm near-infrared-sensitive camera and a $40 \times$ IR-Achroplan objective (Carl Zeiss MicroImaging). The recordings were performed in slices obtained from P27-P35 rats at nearphysiological temperature $\left(31-34^{\circ} \mathrm{C}\right)$ using an EPC-10 amplifier (HEKA Electronics). Currents were filtered at $3 \mathrm{kHz}$, digitized at $10 \mathrm{kHz}$, and acquired using Fitmaster software (HEKA Electronics). D-2-amino-5phosphonovaleric acid (D-APV) effects were quantified by measuring $\mathrm{CF}$ response amplitudes at the time point of maximal reduction, which occurred at $5.7 \pm 1.1 \mathrm{~min}(n=6)$ after wash-in of D-APV. In control experiments, corresponding time points were selected for quantification. Dendritic patch electrodes had electrode resistances of 7-10 M $\Omega$. The saline used were identical to the ones described above.

Confocal calcium imaging. Calcium transients were recorded using a Zeiss LSM 5 Exciter confocal microscope equipped with a $63 \times$ Apochromat objective (Carl Zeiss MicroImaging). Fluorescence was excited at $488 \mathrm{~nm}$ using an argon laser (Lasos Lasertechnik). For calcium imaging experiments, sagittal slices of the cerebellar vermis $(190 \mu \mathrm{m})$ were prepared from 2-4-month-old mice. Purkinje cells were loaded with the fluorescent calcium indicator dye Oregon Green BAPTA-2 $(200 \mu \mathrm{M})$, which was added to the pipette saline described above. The experiments were initiated after the dendrite was adequately loaded with the dye and the fluorescence at regions of interest reached a steady-state level, which typically required $>20 \mathrm{~min}$. The recordings were performed at room temperature. Calcium transients in spines located on the primary dendrite were triggered by single or double ( $40 \mathrm{~ms}$ interval) CF stimulation before and during wash-in of D-APV $(50 \mu \mathrm{M})$ at 1 min intervals. For each sweep, the data acquisition frequency was in the range of 20-100 $\mathrm{Hz}$, depending on the size of the selected region of interest. Fluorescence changes were normalized to resting levels and expressed as the ratio, $\frac{\Delta F}{F}(t)=\frac{[F(t)-F]}{F}$, where $F(t)$ is the fluorescence value at time $t$, and $F$ is the averaged fluorescence obtained during the baseline period preceding the stimulus application.

\section{Results}

To examine whether in the mature cerebellum postsynaptic NMDA receptors are involved in PF synaptic plasticity, we performed whole-cell patch-clamp recordings from Purkinje cells in slices obtained from 2-6-month-old mice. Test responses were monitored in voltage-clamp mode before and after tetanization. For LTD induction, a train of $8 \mathrm{PF}$ stimuli $(100 \mathrm{~Hz})$ was applied in current-clamp mode, followed $120 \mathrm{~ms}$ later by single-pulse CF stimulation. This pairing protocol was applied at $1 \mathrm{~Hz}$ for $5 \mathrm{~min}$, and resulted in a depression of PF-EPSC amplitudes $(60.3 \pm$ $3.8 \%$ of baseline \pm SEM; $t=38-42$ min; $n=13 ; p<0.01$ ) (Fig. $1 A, B)$. When the NMDA receptor antagonist D-APV $(50 \mu \mathrm{M})$ was bath applied, LTD was prevented $(107.0 \pm 14.5 \% ; n=5 ; p>$ 0.05 ) (Fig. $1 A, B$ ). Likewise, LTD was impaired when the NMDA receptor antagonist $\mathrm{MK}-801$ ( $1 \mathrm{mM})$, which acts as an open channel blocker, was added to the pipette saline $(105.6 \pm 10.9 \%$; $n=7$; $p>0.05$ ) (Fig. $1 A, B$ ). As MK-801 was applied postsynaptically, these data suggest that postsynaptic NMDA receptors, expressed in Purkinje cells, are required for PF-LTD induction. When the $\mathrm{PF}+\mathrm{CF}$ coactivation protocol was applied at near-physiological temperature $\left(31-34^{\circ} \mathrm{C}\right)$ instead of room temperature, we observed LTD under control conditions $(63.2 \pm 11.3 \% ; n=5 ; p<$ 


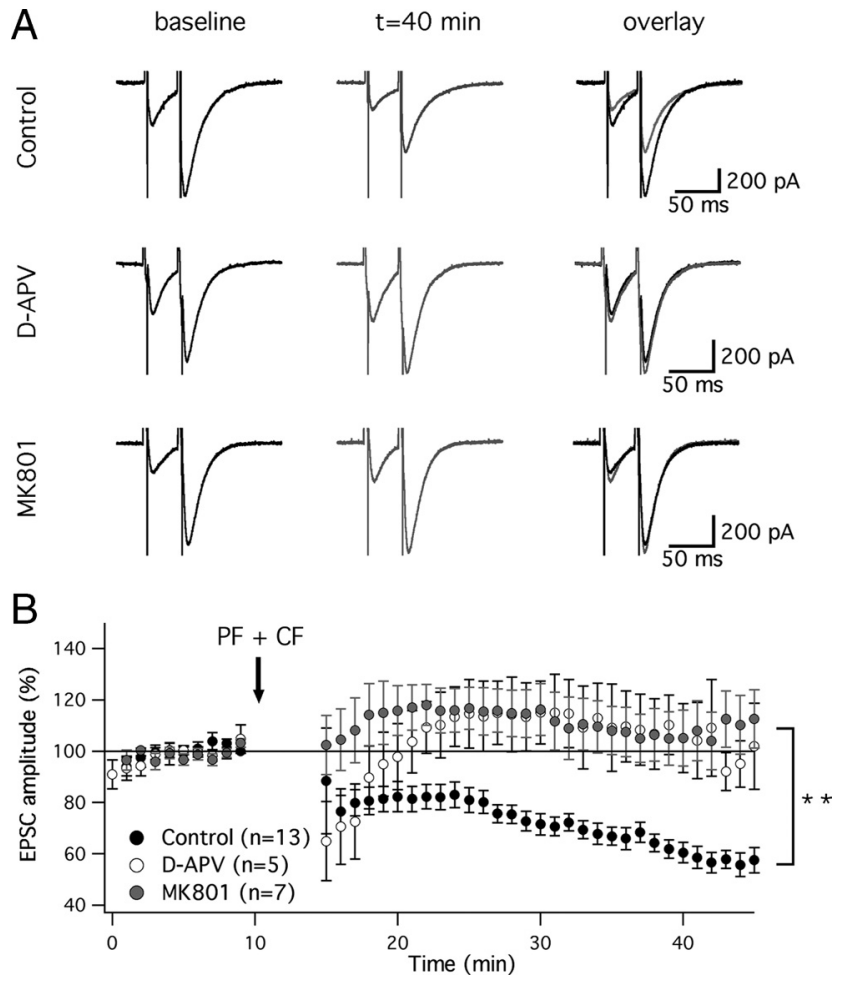

Figure 1. PF-LTD depends on the activation of NMDA receptors. $A$, Typical traces. PF-LTD is observed under control conditions (top), but is blocked in the presence of D-APV (50 $\mu \mathrm{m}$; middle) and MK-801 (1 mM; bottom), respectively. $\boldsymbol{B}$, Time graph showing LTD under control conditions $(n=13)$, and LTD blockade in the presence of D-APV $(n=5)$ and MK-801 $(n=7)$. The arrow indicates the time point of tetanization. Asterisks indicate significant differences between the control and the D-APV/MK-801 groups ( ${ }^{* *} p<0.01$, Mann-Whitney $U$ test). Error bars are mean \pm SEM.

0.05) and blockade of LTD when MK-801 ( $1 \mathrm{~mm})$ was added to the pipette saline $(115.3 \pm 9.2 \% ; n=4 ; p>0.05 ; t=38-42 \mathrm{~min})$ (supplemental Fig. 2, available at www.jneurosci.org as supplemental material), suggesting that NMDA receptor-dependent LTD also occurs under more physiological conditions. In contrast, neither D-APV $(50 \mu \mathrm{M})$ nor MK-801 (1 mM) affected PFLTP as induced by $100 \mathrm{~Hz}$ PF stimulation alone (control: $153.3 \pm$ $10.5 \% ; n=6 ; p<0.01$; D-APV: $143.1 \pm 7.5 \% ; n=5 ; p<0.01$; MK-801: $143.8 \pm 15.6 \% ; n=7 ; p<0.05 ; t=38-42$ min) (Fig. $2 A, B)$. To exclude an involvement of presynaptic NMDA receptors in the blockade of LTD, we tested whether bath application of D-APV $(50 \mu \mathrm{M})$ changes the PPR ratio at either PF or CF synapses. At PF synapses, wash-in of D-APV did not change the EPSC amplitude or the PPF ratio (EPSC 1: $105.6 \pm 7.6 \%$; PPF: $102.4 \pm 3.9 \% ; n=5 ; p>0.05$ ) (supplemental Fig. 1, available at www.jneurosci.org as supplemental material). For CF-EPSC recordings, we bath applied the competitive, low-affinity AMPA receptor antagonist $\gamma$-DGG $(2.5 \mathrm{mM})$ to prevent receptor saturation. Moreover, we added MK-801 to the pipette saline and performed the recordings in $0 \mathrm{mM}$ external $\mathrm{Mg}^{2+}$ to specifically block NMDA receptors in Purkinje cells, while otherwise facilitating NMDA receptor activation. Under these conditions, wash-in of D-APV $(50 \mu \mathrm{M})$ affected neither the EPSC amplitude nor the paired-pulse depression (PPD) ratio (EPSC 1: $102.7 \pm$ 5.1\%; PPD: $97.5 \pm 2.5 \% ; n=5 ; p>0.05$ ) (supplemental Fig. 1 , available at www.jneurosci.org as supplemental material). These results confirm that D-APV does not act on presynaptic NMDA receptors at $\mathrm{PF}$ or CF synapses.
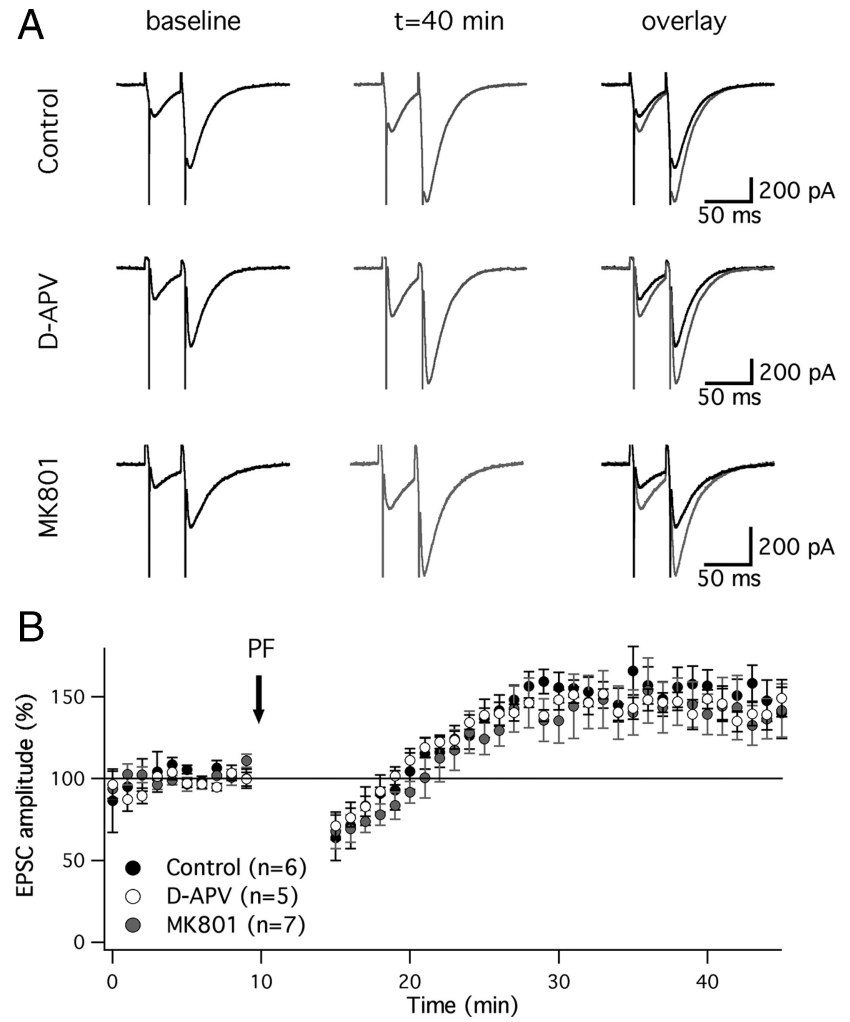

Figure 2. PF-LTP is NMDA receptor-independent. $\boldsymbol{A}$, Typical traces. PF-LTP as recorded under control conditions (top) remains unchanged in the presence of D-APV (middle) and MK-801 (bottom), respectively. $\boldsymbol{B}$, Time graph showing LTP under control conditions $(n=6)$ and in the presence of D-APV $(n=5)$ and MK- $801(n=7)$. The arrow indicates the time point of tetanization. Error bars are mean \pm SEM

How does the suggested involvement of NMDA receptors that are postsynaptically expressed at CF synapses fit with previous reports of PF-LTD being induced by pairing depolarizing pulses (replacing CF activity) with PF activation (Bidoret et al., 2009; Crépel, 2009)? To address this question, we paired depolarizing pulses $(0 \mathrm{mV} ; 100 \mathrm{~ms})$ with double PF stimulation (10 ms interval) at $1 \mathrm{~Hz}$ for $2 \mathrm{~min}$, and repeated this protocol after $5 \mathrm{~min}$ (adapted from Crépel, 2009). This pairing protocol resulted in LTD $(85.6 \pm 4.9 \% ; n=7 ; t=40-45 \mathrm{~min} ; p<0.01)$ (supplemental Fig. 3, available at www.jneurosci.org as supplemental material). However, bath application of D-APV $(50 \mu \mathrm{M})$ did not block this form of LTD $(76.7 \pm 9.0 \% ; n=8$; $p<0.05)$ (supplemental Fig. 3, available at www.jneurosci.org as supplemental material), suggesting that depolarization can bypass the need for NMDA receptor activation, presumably by providing an alternative source of calcium influx. Such a mechanism seems plausible as strong activation of voltage-dependent calcium channels can substitute for NMDA receptor activation in hippocampal LTP induction (Grover and Teyler, 1990).

To directly measure the contribution of NMDA receptors to CF-evoked calcium signaling in CF-contacted spines located on the primary dendrite (Strata and Rossi, 1998), we performed confocal calcium imaging experiments using the calcium indicator Oregon Green BAPTA-2 $(200 \mu \mathrm{M})$. CF activation (2 pulses at a 40 $\mathrm{ms}$ interval) caused pronounced calcium transients in primary dendrite spines (Fig. $3 A-C)$. When D-APV $(50 \mu \mathrm{M})$ was bath applied, both the peak amplitude $(80.2 \pm 4.5 \%$; $n=9 ; p<0.05$; $t=5-10 \mathrm{~min}$ after wash-in) (Fig. $3 A-D)$ and the area under the curve of the calcium transients were reduced ( $800 \mathrm{~ms}$ time win- 

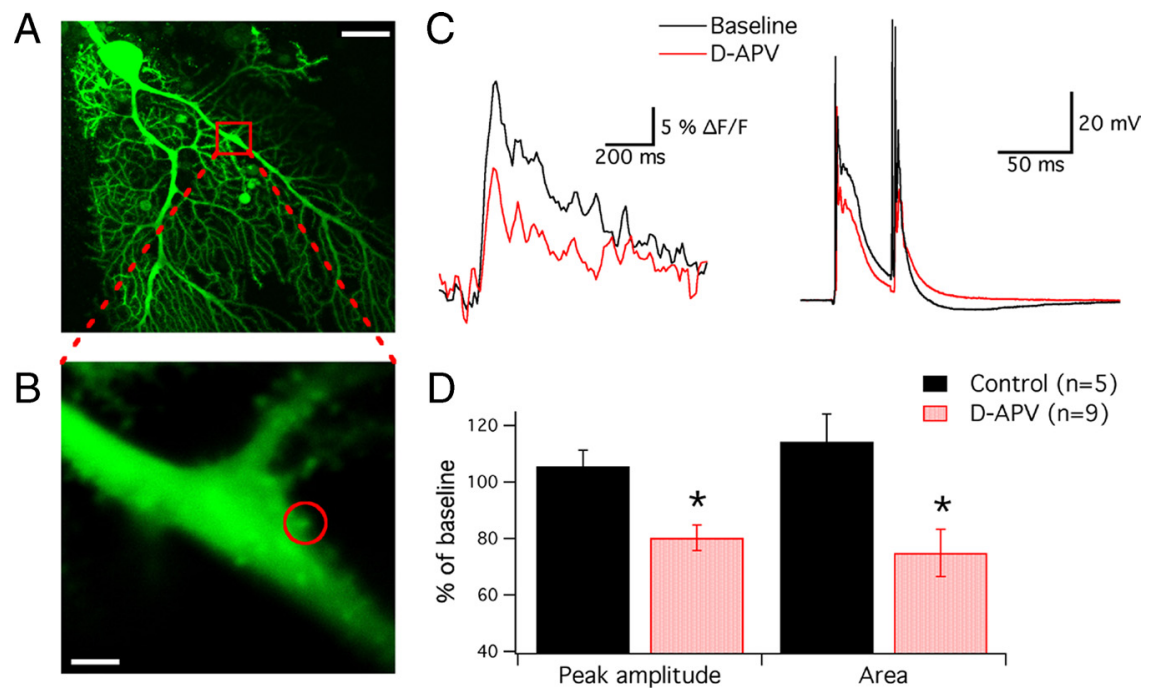

Figure 3. NMDA receptors contribute to CF-evoked spine calcium signaling. $\boldsymbol{A}$, Confocal image of a 2.5 month-old mouse Purkinje cell filled with Oregon Green BAPTA-2 $(200 \mu \mathrm{m})$. $\boldsymbol{B}$, Area enlarged from the red box shown in $\boldsymbol{A}$. The circle indicates the spine region of interest. Scale bars: $A, 20 \mu \mathrm{m} ; \boldsymbol{B}, 2 \mu \mathrm{m}$. $\boldsymbol{C}$, Left, CF-evoked calcium transients (averages of 5 traces) recorded from the dendritic spine shown in $\boldsymbol{B}$ before and during application of D-APV $(50 \mu \mathrm{M})$. Right, Corresponding complex spikes recorded from the soma. $D$, Bar graphs showing D-APV effects on the peak amplitude and area under the curve of the spine calcium transients ( $n=9$; control: $n=5$; ${ }^{*} p<0.05$; Mann-Whitney $U$ test). Error bars are mean \pm SEM.

\section{A}
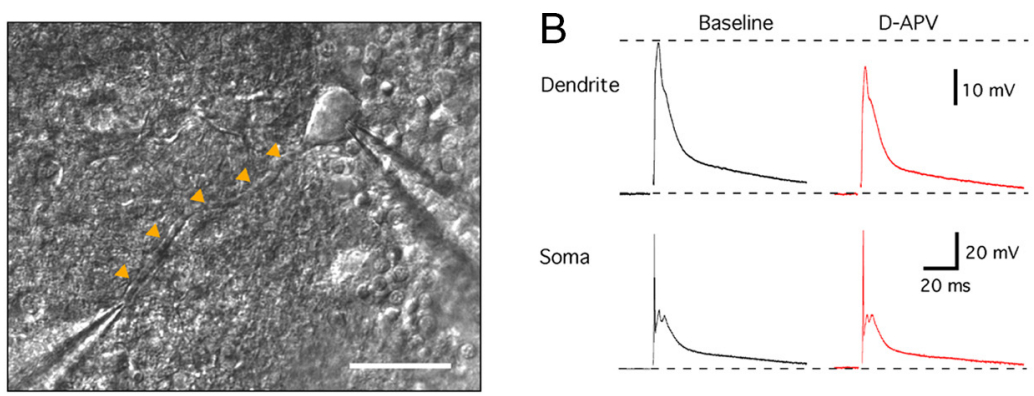

Soma

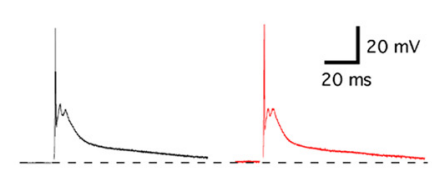

C
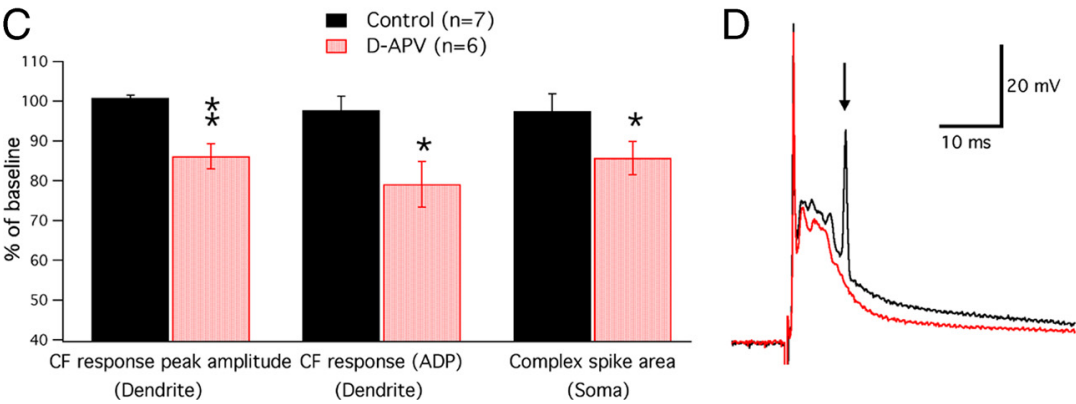

Figure 4. Somatodendritic patch-clamp recordings from rat Purkinje cells reveal an NMDA component in the CF response. $A$, DIC image showing the typical electrode arrangement used for double-patch recordings. The arrowheads outline the course of the dendrite. Scale bar, $40 \mu \mathrm{m}$. B, Dendritically recorded (F responses (top) and somatically recorded complex spikes (bottom) before and during bath application of D-APV (50 $\mu \mathrm{M})$. C, Bar graph summarizing D-APV effects on the peak amplitude of the CF response and the ADP, as well as the complex spike area $\left(n=6\right.$; control: $n=7 ;{ }^{* *} p<0.01$; ${ }^{*} p<0.05$; Mann-Whitney $U$ test). Error bars are mean \pm SEM. $\boldsymbol{D}$, Example of a complex spike recording, in which D-APV application caused a reduction in the number of spikelets (arrow).

dow; $74.8 \pm 8.5 \% ; n=9 ; p<0.05)$ (Fig. $3 A-D$ ), indicating that NMDA receptors contribute to spine calcium signaling. Under control conditions, these parameters remained stable (peak: $105.5 \pm 5.7 \% ; p>0.05$; area: $114.2 \pm 9.9 \% ; p>0.05 ; n=5$ ) (supplemental Fig. 4, available at www.jneurosci.org as supplemental material). To characterize the NMDA component of CF signaling in more detail, we performed somatodendritic double-

\section{Discussion}

patch recordings from $\mathrm{P} 27-\mathrm{P} 35$ rat Purkinje cells. We used rats for these experiments to take advantage of the fact that the size of the Purkinje cell dendrite increases as a function of body size (Harvey and Napper, 1991), thus facilitating patch-clamp access. To achieve optimal conditions for successful cell surface cleaning under IR-DIC-guided visual control, and ultimately dendritic patch formation, we used slices obtained from young adult animals. We performed dendritic recordings at an average distance from the soma of $95 \pm 6 \mu \mathrm{m}(n=13)$. At these dendritic locations, CF stimulation results in large EPSPs that may or may not contain additional spike components (Davie et al., 2008; Ohtsuki et al., 2009) (Fig. $4 A, B$ ). Upon wash-in of D-APV (50 $\mu \mathrm{M})$, both the peak amplitude of the CF response and the afterdepolarization (ADP; 20-40 ms time window) were reduced (peak: $86.2 \pm 3.2 \% ; p<0.01$; ADP: $79.1 \pm 5.7 ; p<0.05 ; n=6 ; t=6$ min after wash-in) (Fig. $4 B, C$ ) but remained stable under control conditions (peak: $100.9 \pm 0.6 \%$; ADP: $97.7 \pm 3.6 \% ; n=7$; $p>0.05$ ) (supplemental Fig. 4 , available at www.jneurosci.org as supplemental material). In correspondence with these dendritic alterations, D-APV reduced the somatically recorded complex spike area (50 ms time window: $85.7 \pm 4.2 \%$; $n=6 ; p<0.05$; control: $97.6 \pm 4.3 \%$; $n=7 ; p>0.05$ ) (Fig. $4 B, C$ ). In three of six cells, the somatic recordings showed an accompanying reduction in the spikelet number (Fig. 4D). These data reveal a significant NMDA receptor-mediated component of CF signaling. In separate recordings from rat Purkinje cells (P25P66), we confirmed that in rats, just like in mice, LTD is induced under control conditions $(65.2 \pm 8.8 \% ; n=5 ; p<0.05 ; t=$ $45-50 \mathrm{~min}$ ), but is blocked in the presence of D-APV ( $50 \mu \mathrm{M} ; 141.1 \pm 25.6 \% ; n=4$; $p>0.05$ ) (supplemental Fig. 5, available at www.jneurosci.org as supplemental material). Likewise, the amplitude of calcium transients is reduced in rat Purkinje cells (P33-P78) upon wash-in of D-APV (50 $\mu \mathrm{M}$; peak amplitude: $76.4 \pm 5.0 \%$; area under the curve: $71.3 \pm 10.6 \% ; n=7$; $p<0.05$ ) (supplemental Fig. 5, available at www.jneurosci.org as supplemental material).

Our results show that the previous notion that postsynaptic NMDA receptors do not play a role in Purkinje cell synaptic integration and plasticity cannot be upheld. Rather, a picture emerges in which NMDA receptors are expressed in Purkinje cells at a late developmental onset, reaching high levels of 
expression at $\sim 8$ weeks after birth (Piochon et al., 2007), and that therefore a physiological role of Purkinje cell NMDA receptors can only be demonstrated in the mature cerebellum. Consequently, previous studies using young adult rodents did not report an involvement of Purkinje cell NMDA receptors in cerebellar plasticity (Casado et al., 2002; Canepari and Vogt, 2008). Our observation that NMDA receptors contribute to spine calcium signaling and LTD induction in rats suggests that NMDA receptors play a similar role in PF synaptic plasticity in rats.

Here, we show that in the mature mouse cerebellum, postsynaptic NMDA receptors assume a key role in the control of bidirectional PF plasticity, selectively promoting PF-LTD induction. It is likely that the LTP induction process is less affected by NMDA receptor blockade because the calcium threshold for LTP induction is lower than that for LTD induction (Coesmans et al., 2004; Jorntell and Hansel, 2006). The moderate potentiation we observed when the LTD protocol was applied in the presence of either D-APV or MK-801 suggests that the resulting calcium transient might fall into a range required for potentiation, without allowing LTP to reach its full maximum. Alternatively, NMDA receptor-mediated calcium transients might be specifically required for the activation of $\alpha$-CaMKII and $\beta$-CaMKII (Thalhammer et al., 2006). Following application of an LTD protocol, similar low-amplitude potentiation has indeed been observed in adult $\alpha$-CaMKII and $\beta$-CaMKII knock-out mice, respectively (Hansel et al., 2006; van Woerden et al., 2009). Our previous work has shown that NMDA receptors are located at CF to Purkinje cells synapses in the mature cerebellum, while single PF-EPSCs do not show detectable NMDA components (Piochon et al., 2007). In the present study, we demonstrate an NMDA component in both dendritically recorded CF responses and CFtriggered spine calcium transients, thus confirming that functional NMDA receptors are expressed at the CF input sites. However, we cannot exclude the possibility that NMDA receptors might exist at PF synapses as well and contribute to the local calcium transient, as in our LTD- and LTP-inducing protocols the $\mathrm{PF}$ input is tetanized at $100 \mathrm{~Hz}$, thus providing a stronger depolarizing drive than single-pulse stimulation. At the CF input, in contrast, single-pulse stimulation leads to a large all-or-none response in the dendrite (Davie et al., 2008; Ohtsuki et al., 2009), which is strong enough to recruit NMDA receptor signaling, and ultimately evokes a complex spike in somatic recordings (Schmolesky et al., 2002). In three of six cells, we observed that NMDA receptor blockade reduces the number of spikelets in the complex spike waveform, specifically affecting the last spikelet. This contribution of NMDA receptor signaling is relevant, as the probability for axonal propagation is particularly high for spikelets that occur late in the complex spike (Khaliq and Raman, 2005; Monsivais et al., 2005).

The late developmental onset of functional NMDA receptor expression in mature Purkinje cells raises the question of the physiological significance of such a late switch toward NMDA receptor-dependent plasticity. It is evident that earlier during maturation NMDA receptor-independent learning correlates allow for fine adjustment of movements and cerebellar motor learning. It is possible that the late expression of NMDA receptors protects Purkinje cells, which are highly susceptible to glutamate-mediated excitotoxicity (Slemmer et al., 2005), from excessive calcium influx during maturation. Alternatively, NMDA receptor-mediated calcium signaling might allow the CF input to contribute to supralinear calcium signaling required for PF-LTD induction despite a growing den- dritic tree during maturation, and thus the growing distances between the CF input site and distal PF synapses. This heterosynaptic CF contribution is a unique motif of cerebellar plasticity. Our observation that NMDA receptor signaling is needed for LTD, but not LTP induction, is another feature that distinguishes cerebellar LTP and LTD from their hippocampal counterparts.

\section{References}

Bidoret C, Ayon A, Barbour B, Casado M (2009) Presynaptic NR2Acontaining NMDA receptors implement a high-pass filter synaptic plasticity rule. Proc Natl Acad Sci U S A 106:14126-14131.

Bliss TV, Collingridge GL (1993) A synaptic model of memory: long-term potentiation in the hippocampus. Nature 361:31-39.

Canepari M, Vogt KE (2008) Dendritic spike saturation of endogenous calcium buffer and induction of postsynaptic cerebellar LTP. PLoS One 3:e4011.

Casado M, Isope P, Ascher P (2002) Involvement of presynaptic N-methyl-Daspartate receptors in cerebellar long-term depression. Neuron 33:123-130.

Coesmans M, Weber JT, De Zeeuw CI, Hansel C (2004) Bidirectional parallel fiber plasticity in the cerebellum under climbing fiber control. Neuron 44:691-700.

Crépel F (2009) Role of presynaptic kainate receptors at parallel fiberPurkinje cell synapses in induction of cerebellar LTD: interplay with climbing fiber input. J Neurophysiol 102:965-973.

Davie JT, Clark BA, Häusser M (2008) The origin of the complex spike in cerebellar Purkinje cells. J Neurosci 28:7599-7609.

Grover LM, Teyler TJ (1990) Two components of long-term potentiation induced by different patterns of afferent activation. Nature 347:477-479.

Hansel C, de Jeu M, Belmeguenai A, Houtman SH, Buitendijk GH, Andreev D, De Zeeuw CI, Elgersma Y (2006) $\alpha$ CaMKII is essential for cerebellar LTD and motor learning. Neuron 51:835-843.

Harvey RJ, Napper RM (1991) Quantitative studies on the mammalian cerebellum. Prog Neurobiol 36:437-463.

Ito M (2002) The molecular organization of cerebellar long-term depression. Nat Rev Neurosci 3:896-902.

Ito M, Sakurai M, Tongroach P (1982) Climbing fibre induced depression of both mossy fibre responsiveness and glutamate sensitivity of cerebellar Purkinje cells. J Physiol 324:113-134.

Jörntell H, Hansel C (2006) Synaptic memories upside down: bidirectional plasticity at cerebellar parallel fiber-Purkinje cell synapses. Neuron 52:227-238.

Khaliq ZM, Raman IM (2005) Axonal propagation of simple and complex spikes in cerebellar Purkinje neurons. J Neurosci 25:454-463.

Konnerth A, Dreessen J, Augustine GJ (1992) Brief dendritic calcium signals initiate long-lasting synaptic depression in cerebellar Purkinje cells. Proc Natl Acad Sci U S A 89:7051-7055.

Lev-Ram V, Wong ST, Storm DR, Tsien RY (2002) A new form of cerebellar long-term potentiation is postsynaptic and depends on nitric oxide but not cAMP. Proc Natl Acad Sci U S A 99:8389-8393.

Llano I, Marty A, Armstrong CM, Konnerth A (1991) Synaptic- and agonist-induced excitatory currents of Purkinje cells in rat cerebellar slices. J Physiol 434:183-213.

Miyakawa H, Lev-Ram V, Lasser-Ross N, Ross WN (1992) Calcium transients evoked by climbing fiber and parallel fiber synaptic inputs in guinea pig cerebellar Purkinje neurons. J Neurophysiol 68:1178-1189.

Monsivais P, Clark BA, Roth A, Häusser M (2005) Determinants of action potential propagation in cerebellar Purkinje cell axons. J Neurosci $25: 464-472$.

Ohtsuki G, Piochon C, Hansel C (2009) Climbing fiber signaling and cerebellar gain control. Front Cell Neurosci 3:4.

Perkel DJ, Hestrin S, Sah P, Nicoll RA (1990) Excitatory synaptic currents in Purkinje cells. Proc Biol Sci 241:116-121.

Piochon C, Irinopoulou T, Brusciano D, Bailly Y, Mariani J, Levenes C (2007) NMDA receptor contribution to the climbing fiber response in the adult mouse Purkinje cell. J Neurosci 27:10797-10809.

Qiu DL, Knöpfel T (2007) An NMDA receptor/nitric oxide cascade in presynaptic parallel fiber-Purkinje neuron long-term potentiation. J Neurosci 27:3408-3415.

Renzi M, Farrant M, Cull-Candy SG (2007) Climbing-fibre activation of NMDA receptors in Purkinje cells of adult mice. J Physiol 585:91-101. 
Ross WN, Werman R (1987) Mapping calcium transients in the dendrites of Purkinje cells from the guinea-pig cerebellum in vitro. J Physiol 389:319-336.

Sakurai M (1990) Calcium is an intracellular mediator of the climbing fiber in induction of cerebellar long-term depression. Proc Natl Acad Sci U S A 87:3383-3385.

Schmolesky MT, Weber JT, De Zeeuw CI, Hansel C (2002) The making of a complex spike: ionic composition and plasticity. Ann N Y Acad Sci 978:359-390.

Shin JH, Linden DJ (2005) An NMDA receptor/nitric oxide cascade is involved in cerebellar LTD but is not localized to the parallel fiber terminal. J Neurophysiol 94:4281-4289.
Slemmer JE, De Zeeuw CI, Weber JT (2005) Don't get too excited: mechanisms of glutamate-mediated Purkinje cell death. Prog Brain Res 148:367-390.

Strata P, Rossi F (1998) Plasticity of the olivocerebellar pathway. Trends Neurosci 21:407-413.

Thalhammer A, Rudhard Y, Tigaret CM, Volynski KE, Rusakov DA, Schoepfer R (2006) CaMKII translocation requires local NMDA receptormediated Ca2 + signaling. EMBO J 25:5873-5883.

van Woerden GM, Hoebeek FE, Gao Z, Nagaraja RY, Hoogenraad CC, Kushner SA, Hansel C, De Zeeuw CI, Elgersma Y (2009) $\beta$ CaMKII controls the direction of plasticity at parallel fiber-Purkinje cell synapses. Nat Neurosci 12:823-825. 